\title{
BUILDING A MORE INTIMATE CONNECTION BETWEEN SPIRITUALITY AND QUALITY SERVICE PERFORMANCE AT WORK
}

\author{
Mazni Saad ${ }^{*}$, Norliana Ahmad Shah ${ }^{2}$, \\ Noor Malinda Mohamed Mohan ${ }^{2}$ and Halimi Poniran ${ }^{2}$ \\ $1 *$ Kulliyah of Languages and Management, \\ International Islamic University Malaysia, Johor, Malaysia \\ E-mail: maznisaad@iium.edu.my
}

${ }^{2}$ Faculty of Business and Accountancy, Universiti Selangor, Selangor, Malaysia E-mail:norliana@unisel.edu.my; malinda@unisel.edu.my; halimi_poniran@unisel.edu.my

\begin{abstract}
One of the biggest challenges in tertiary education is that lecturers need to be versatile and able to quickly adapt to different challenges in many different functions or activities such as recruiting new student. Moreover, a higher timetable load may contribute to emotional stress, and lecturers need to know how to work with unpredictable situations like difficult students or office politics. Thus, lecturers need a huge support system in place to deal with these situations at work, but information on lecturers' coping abilities, specifically referred to as spiritual intelligence (SQ) is limited and not yet understood. Therefore, this study aims to examine how the SQ affects performance of lecturers in privately-owned universities by measuring the quality services. Based on the questionnaires distributed to lecturers in selected privately-owned universities, this study found that the SQ level among the young lecturers was quite high. It was also revealed that all sub-dimensions of SQ were positive and also significantly affected the performance of the lecturers. The standardised coefficient beta values indicated that the sub-dimensions of Transcendence contributed to 37\%, while Meaning contributed to $31 \%$ Service Quality.
\end{abstract}

Keywords: service quality, spiritual intelligence, privately-owned university, Malaysia

ARTICLE INFO

Article History:

Received: 18 February 2019

Accepted: 15 July 2019

Published: 31 August 2019 


\section{INTRODUCTION}

Lecturers are the most critical human capital in the education industry as they play a vital role. In class, they not only have to get the students to think and talk about subject matter, but they are also responsible for building the students' confidence about their learning so that they can apply the knowledge acquired to their chosen fields of study. The lecturer's job is often fraught with difficulty at adapting to the increasing popularity of new learning models and tools such as problem-based learning, integrated cumulative grade point average (iCGPA), and many others that involve plenty of administrative work. Mansor and Han (2013) highlighted several other challenges faced by Malaysian universities such as working towards being recognised by the national ranking system (SETARA), being involved in an academic performance audit and being given autonomy for self-accreditation (SWA), while at the same time ensuring high graduate employability. Nowadays, lecturers face another great challenge that requires them to be actively involved in research contributing not only to their key performance index but also towards helping organisations remain competitive in the university's complex environment. Very often lack of appropriately trained staff adds pressure to the teaching profession. Society too expects the professional lecturer to share knowledge with the community. These dynamic and competitive perimeters must be assured so that customers are happy and satisfied (Saad, Husain, Nawi, \& Mahyuddin, 2017).

Lecturers have to be a transformer of the inner being; nourishing the young minds to be great, but it is not an easy task to bring out the best in every person. However, quality lecturers are found to have SQ as the basis of an existing level of consciousness, awareness and inner connection. The guiding principle behind wholeness, relationships, inner wisdom and inner authority comes from one's passion and commitment to work or better known as the spirit at work (Chin, Anantharaman, \& Tong, 2011). Accordingly, McGuire (1993) defines SQ as the ability to act with awareness and compassion while maintaining health, inner and outer peace (tolerance), regardless of the situation.

However, becoming an effective facilitator can sometimes lead to personal frustration. Failure to perform our role effectively will cause 
huge consequences in the long run. Teaching in a university, particularly a privately-owned one is demanding and complex, and lecturers need to be good not only in controlling their emotions, but also be spiritually balanced while keeping abreast with new changes that are currently happening to our global world (Saad, Hussain, Rani, \& Ghani, 2010). Private universities in Malaysia like their public counterparts focus more on complying with the requirements of accreditation, while at the same time giving lecturers different career routes for advancement. Many expose their employees to on-the-job training or further education, which seems to have resulted in a higher turnover rate compared to public universities (Narimawati, 2007). Typically, private university lecturers seem to be working in a stressful environment where students' expectations are always high; teaching responsibilities are countless while also being burdened continuously with research and administrative work. Subsequently, lecturers tend to experience many negative emotions such as tension, hostility, depression, anger, nervousness and frustration (Ismail, Suh, Ajis, \& Dollah, 2009).

For years scholars have been examining Emotional Intelligence (EQ) which is defined by Mayer and Salovey (1993) as the ability to monitor one's feelings and emotions to discriminate among them; and to use this awareness of emotions to guide one's thinking and action. These studies have tried to show the connection between EQ and performance. Many studies, for instance, Akintayo and Babalola (2012) found the connection between EQ and the workers' execution of activities, work fulfilment, work contribution and hierarchical responsibility as critical and significant. In recent investigations on private university lecturers, Ahmad Shah, Saad, Mohamed Mohan, and Poniran (2018) found that the EQ dimensions; self-regulation and social skills are statistically significant in predicting job effectiveness.

Further, performance at work was successfully proven when the EQ was tested even among a group (Elizabeth \& Steven, 2007). Jha and Singh (2012) tested the EQ dimensions of self-awareness, empathy, integrity, selfmotivation, emotional stability, managing relationships, self-development, values orientation, commitment and altruism on 250 respondents using the Teacher Effectiveness Scale (TES) and the Teacher Rating Scale (TRS) and found a positive correlation between EQ and teaching effectiveness. Apparently, teaching individuals with EQ as part of social intelligence regulates the personal as well as the emotions and feelings of others. 
While EQ is about the ability to identify and manage emotions, Spiritual Intelligence (SQ) is a higher dimension of intelligence that results in more profound meaning and purpose. SQ has also recently been connected to the effectiveness of group training, maximizing the service industry's bottom line, fostering leadership, learning and education, corporate disclosure quality, and human resource development, to name few (Wirawan, Jufri, \& Patak, 2018; Salehi, Mirzaee, \& Yazadani, 2017; Rupcic, 2017; Nolan-Aranez \& Ludvik, 2018; Mahmood, Arshad, Ahmed, Akhtar, \& Khan, 2018; Ramachandra, Krauss, Hamzah, \& Idris, 2017).

At a higher level, SQ is no longer a new concept to consider when dealing with improving performance. On top of a better understanding of what others are feeling through EQ adoption, SQ helps to improve interaction through logical thinking process and inner wisdom. Using SQ as a driver can help organisations become excellent by focusing on a person's inner quality when escalating his or her performance at the workplace (Haji, Bemby, \& Sentosa, 2013).

Spirituality exists in the heart of every individual as it is concerned with the inner life, of mind and spirit. Thus, it appears that spiritually intelligent people will seek value and meaning in their work as they try to achieve a good outcome. According to Moore and Casper (2006), spirituality is some internal substance, a value, a belief, an attitude, or emotion that affects people's behaviour.

Spirituality relates to the way we perceive ourselves as it focuses on our inner world. Abels (2000) meanwhile defines spirituality as a desire for social justice and respect for all persons regardless of their circumstances. The author connects it to the social work concept of equality, autonomy, human development and privacy. Harries (1998) also links spirituality to social justice and views it as the driving force that sustains her social work practices. On the other hand, Vaughan (1991) sees spirituality as enhancing the social work concept of self-esteem and personal responsibility. In other empirical studies (e.g. Saad, See, Adil, \& Kassim, 2015; Saad, See, Adil, \& Ab Manan, 2014), SQ has shown a positive and significant influence on leadership effectiveness. SQ is much needed in a mature leadership; where the leaders use their heart and soul as personal growth responding to certain situations. 
Many of the studies mentioned above are all positive about the spirituality of one's mind and spirit and the value of oneself in social life and at work. Of interest to this study is how a private-owned university lecturer values work about imparting knowledge through quality academic programs. This study, therefore, investigates SQ among the lecturers of private universities and how it impacts performance by measuring the quality services they offer.

\section{LITERATURE REVIEW}

\section{Spiritual Intelligence}

Lecturers have to be transformers of the inner being; nourishing young minds to be great, but it is not an easy task to bring out the best in every person. However, quality lecturers are found to have SQ as the basis of an existing level of consciousness, awareness and inner connection. The guiding principle behind wholeness, relationships, inner wisdom and inner authority comes from one's passion and commitment to work or better known as the spirit at work (Chin, Anantharaman, \& Tong, 2011). Accordingly, McGuire (1993) defines SQ as the ability to act with awareness and compassion while maintaining health, inner and outer peace (tolerance), regardless of the situation.

However, there are several arguments that differentiate spirituality from religion. According to Van Niekerk (2018), the idea of spirituality is the quest to distinguish its distinct identity from that of religion. Although there is a close and overlapping relationship between the meaning of religion and spirituality, both relate to a belief in the Almighty, albeit with some differences.

Pargement (1999) believes that religion is related to organisational affairs, rituals and ideology, whereas spirituality has a relationship with the personal and influence affairs arising from experience and thought. Furthermore, Jafari and Rastegar (2007) refers to the concept of spirituality as a private and personal activity at finding the meaning of one's experience in life. 
The concept of SQ has become an essential part of our lives as well as the workplace. Perez (2012) states that SQ is one of several types of intelligence that can be developed independently and can contribute to physiological well-being and overall healthy human development. Furthermore, Zohar and Marshall (2000) define SQ as the mental aptitude used by human beings to address and find solutions and value in life. Hence, SQ has significant benefits for an organisation and is vital in helping a person to explore the innermost resources of their spiritual capacity.

These current studies provide even more proof that the connection between SQ and service quality is positive. This study has adopted the five dimensions of SQ from Amram and Dryer (2007); namely, truth, grace, transcendence, meaning, and consciousness. Truth is about being able to openly accept and forgive, and showing curiosity and love for all God's creations, including respecting diverse spiritual philosophies and traditions. Grace is about loving life and drawing inspiration from all things beautiful and happy that one experiences at every moment thus contributing to one's general well-being. Transcendence, on the other hand, is about being spiritually aligned which allows you to discover the purpose and meaning to your life. It is about knowing your inner and deeper self that nourishes health and well-being and improving work performance.

There are five subscales of Transcendence; Higher self, Holism, Practice, Relatedness and Sacredness (Amram \& Dryer, 2007). In a study by Piedmont (1999), spiritual transcendence is focused on measuring the individual's independent qualities as described by the Five-Factor Model of Personality. As for one of the scales, holism, a study by, e.g. Saad, See, Adil, and Md Kassim (2015), shows holistic view having a significantly positive impact on the quality of food served by employees in food service institutions. They concluded that the food service employees' holistic value tended to be towards improved food performance.

This means, one of the dimensions of SQ, in the meantime is about finding meaning in one's experience, linking values to these experiences and interpreting them in ways that will enhance one's general wellbeing notwithstanding problems and difficulties. There are two subscales to meaning: purpose and service. The purpose is the reason why people work and whether it is a form of personal advancement, while Service expresses 
how people see work; whether work is fun and enjoyable or just a chore (Amram \& Dryer, 2007).

According to Amram and Dryer (2007), consciousness refers to the development of awareness and self-knowledge, featuring intuitive transrational knowing, mindfulness and spiritual practices. Consciousness is the ability to raise awareness, to tap into one's instincts and to integrate different perspectives towards improving one's daily work (Chin, Anantharaman, \& Tong, 2011). Furthermore, Hay and Nye (1998) describe consciousness as a distinctive property of mental activity, including cognition. It also recognises emotion, action and sensation. Thus, embracing SQ could make a person's life more self-satisfying and pleasant.

\section{Growing Importance of Spiritual Intelligence at Work}

Most organisations today realise that it is not enough to expect employees to be emotionally intelligent only. Incorporating spirituality at the workplace would mean having employees with a stronger orientation and purpose. Watkins (2003) argues that organisations have started to recognize the importance of valuing the whole person from a spiritual perspective rather than just the skills the person has for the job. An increasing number of organisations have started incorporating spiritual practices within their organisational system. According to Srivastava and Misra (2012), people want to see value and meaning in their life and work and at the same time make a difference to others.

Spirituality is the ultimate level of intelligence without any religious bias to help one understand self. Although some literature argues that SQ is about religiosity (Crisp, 2018; Gill, Mand, Biger, \& Mathur, 2018; Petrosko \& Alagaraja, 2017), quite some studies have however attempted to show the positive effects of religiosity in managing conflict or as a research strategy in management. For instance, Shaikh (2018) argues that although there is a mutual co-existence of both empirical knowledge (science) and religion, only religiosity can be the arbiter of moral, philosophical, political and social matters. Some studies have discovered that both spirituality and religion are significantly related and are strong predictors of mental well-being (i.e., emotional, social, and psychological), job satisfaction and productivity, and an intention to leave a job (Joshanloo, 2010; Petrosko \& Alagaraja, 2017). 
Currently, SQ does provide employees with a sense of interconnectedness as they can make meaningful contributions to the community. However, Fry (2003) claims that the $21^{\text {st }}$ century learning organisations are highly disorganised and in directions need to be rapidly and radically changed into spirituality-based business organisations. They also need to be productive and intrinsically motivated in order to confront new challenges successfully. This organisational transformation also includes treating workers well and spiritually engaging them in the organisation's purpose thus enhancing greater employee loyalty and performance. This is reaffirmed by the thematic review of SQ by Mahmood et al. (2018), who concluded that SQ is a very crucial component of organisational development that leads to better performance.

\section{Service Quality}

The main focus of academic research in higher education in the past few years has been directed towards quality improvement and its initiatives (Avdjieva \& Wilson, 2002, Barnes \& Vidgen, 2003; Lassar, Manolis, \& Winsor, 2000). In the education sector, service quality with the aid of the support services is capable of meeting both the lecturers' as well as students' needs. The management of these learning institutions too is confident of achieving their stated goals, aims and objectives. According to Smith (2000), this is due to information received from customer experience (students and lecturers) which is vital in developing external benchmarking programs that improve service quality.

Sachro and Pudjiastuti (2013) relate service quality to satisfaction. They noted that service quality has a significant effect on customer satisfaction. Their service quality consisting of tangibility, empathy, responsiveness, reliability and assurance have been shown to improve customer satisfaction. Similarly, Agbor (2011) found that reliability and empathy are significantly related to customer satisfaction but not responsiveness; service quality is significantly associated with customer satisfaction.

Accordingly, O'Neill and Palmer (2004) also emphasised the importance of expectations and perceptions when defining service quality. They define service quality in higher education as the difference between what a student expects to receive and his or her perceptions of actual delivery. 
Meanwhile, Parasuraman, Zeithaml, and Berry (1988) indicated that the measurement of service quality is accomplished by considering the variance between the clients' expectations of the services before delivery and the perception of the received services attained. Parasuraman et al. (1985, 1991, and 1994) define and measure service quality along the five dimensions of assurance, reliability, responsiveness, empathy, and tangibility.

An alternative model was introduced by Rust and Oliver (1994) who categorised service quality into three components, i.e. service product, service delivery and service environment. Later, efforts by Dabholkar, Thorpe, and Rentz (1996) and Brady and Cronin (2001) further advanced the conceptualisation of service quality towards a multidimensional, hierarchical construct to reflect the complexity of service quality evaluations.

\section{Relationship between Spiritual Intelligence and Service Quality}

Quality has been highlighted as the hallmark of the products of the service industry. It is also a quality that gives the industry a competitive advantage in today's world of economic integration, sustainability, and globalisation. In order to remain, organisations maintain competitiveness by increasing the quality of their services, while considering the preferences and expectations of the consumer.

According to Flynn (2005), one of the most critical factors in a service organisation that affects employees' perception of service quality is the interaction behaviour between employee and customers. Customers see service providers as part of the service itself. Customer satisfaction and their perceptions of service quality will increase if employees behave properly when providing services. Meanwhile, Hays and Hill (2006) revealed that service organisations with motivated employees could improve service quality, customer satisfaction and loyalty.

There are various ways of measuring service quality. Some scholars claimed that service quality is the total of customers' perceptions and bears no relation to customers' expectations (Saleh \& Ryan, 1991; Saravanon \& Roak, 2007; Yarmohammadian, Foroughi Abari, Anasri, \& Kiani, 2009). Meanwhile, other scholars claimed that service quality could be measured 
best by looking at the indicators of quality or performance (Al-Turki \& Duffuaa, 2003), while some others argued that indicators which are measured quantitatively are not informative and do not speak for quality enhancement (White, 2007). In the absence of objectivity, quality should be measured by considering consumers' perceptions of service quality and must identify their strengths and weaknesses by these perceptions. This leads to the design of an instrument that measures service quality and gives the results in tangible form.

Numerous studies have documented the importance of SQ on work performance. There is ample evidence to show that spiritual employees are better in managing themselves and understand customer's attitude in a service interaction. According to Rezai et al. (2011), SQ has a positive effect on marketing performance, while Javaheri et al. (2013) stated that SQ has a significant and positive effect on service quality. The results of the research show that elements of SQ affect service quality. Furthermore, Nadi and Golpalvar (2011) showed that SQ has a positive effect on loyalty. The result reveals that eleven subscales of spirituality have a significant relationship with loyalty.

However, the relationship between neglecting development with elevation and spirituality with loyalty seems contrary. The consequences of the stepwise regression demonstrate a critical connection between loyalty and religious and spiritual value. The results are with a variance of 29 per cent in clarifying loyalty in the initial step; religious and spiritual value alongside obligation for self-awareness and development with 36.2 per cent variance clarifying loyalty in the second step; and religious and spiritual values, responsibility towards self-improvement and positive work unit value with 40.6 per cent fluctuation clarifying loyalty in the third step respectively. The findings of this study demonstrate religious and spiritual values, obligation towards improving and developing oneself and positive work unit as the most effective and vital dimensions of spirituality. These are the dimensions that should, therefore, be strengthened to build loyalty.

George and Visvam (2013) in their study revealed the relationship between SQ, academic achievement and teacher effectiveness of student teachers at the elementary level. Teachers with a high SQ can see things in a broader context. Through a high SQ, the effectiveness of student teachers 
can be enhanced which will lead to better relationships in their personal and professional life. SQ in this study is composed of life with purpose and meaning, equal dignity, the wisdom of life, care for others, and the right relationship with oneself, others and all of God's creation. SQ's influence was also tested on the nurses' work performance in government hospitals of the East Coast of Malaysia Rani, Ghani, and Ahmad (2013). The study's SQ constructs were consciousness, transcendence, meaning, truth, and grace. Work performance was measured in terms of leadership, critical care, teaching collaboration, planning evaluation, inter-peer-communication, and professional development. The confirmatory analysis of the 506 female respondents found both positive and significant results relating SQ to job performance.

This study is derived from a linked causal model proposed by Tischler, Bibierman, and McKeage (2002). Their proposed SQ is independently linked with performance. The model was tested seven years after the proposal by Martin and Hafer (2009) who focused on SQ dimensions. Service quality was measured by assurance, reliability, responsiveness, empathy, and tangibility.

This present study has developed a theoretical framework (see Figure 1) proposing SQ as a factor of influence in performance which is measured by Service Quality. The posited hypothesis is: SQ (truth, grace, transcendence, meaning, and consciousness) has an impact on lectures' performance and can be measured by quality services.

Independent variable

Dependent variable

Spiritual Intelligence:

- Truth

- Grace

- Transcendence

- Meaning

- Consciousness

Performance:

Service Quality

Figure 1: Theoretical framework 


\section{RESEARCH METHODOLOGY}

A linked causal model proposed by Tischler, Bibierman, and McKeage (2002) became the basis of this present study. The model was only tested seven years later by Martin and Hafer (2009) who reduced Ashmos and Duchon's (2000) 66 items to 15. These were reworded to suit a school environment's spirituality. However, Martin and Hafer's SQ model which was measured by a cumulative GPA (CGPA) was not significant to performance. Martin and Hafer claimed that their study was not totally comparable to Tischler, Bibierman, and McKeage's who measured SQ as a competency-based variable. This study's SQ, on the other hand, measures the competency-based variable of service quality.

SQ in this study incorporates the five sub-dimensions of truth, grace, transcendence, meaning, and consciousness. It consists of 25-items (five items in each dimension), which have been reduced from the original scale of 45-items from Rani, Ghani, and Ahmad (2013). Rani, Ghani, and Ahmad (2013) originally adapted questions from Amram \& Dryer's Integrated Spiritual Intelligence Scale (Amram \& Dryer, 2007), where lecturers' work performance was measured using service quality that was adapted from Sureshchandar et al. (2001). They distinguished five essential variables of service quality from the perspective of the customers: core services or service products, human aspect of service delivery, systematisation of service delivery - non-human element, tangible service (servicescapes), and social responsibility.

Madhu et al. (1996) examined the influence of the quality dimensions on nine component items that make up organisational performance for both manufacturing and service firms. Information derived from the study shows that when compared to manufacturing, practising managers in the service sector seems not to have understood some of the relevance and value of quality management activities. Kuei and Madhu (1995) also indicated a strong association between quality measures (customer satisfaction, employee satisfaction and employee service quality) and organisational performance.

This present study measures SQ and Service Quality on a six-point Likert scale of $1=$ strongly disagree to $6=$ strongly agree, avoiding midpoints 
as an option. Brown (2006) was cited arguing even-numbered Likert scales leading the response to set a certain point by clarifying their positions on the variable items (Croasmun \& Ostrom, 2011). A questionnaire survey was administered at 20 private universities in Selangor where a simple random sampling method was employed in the selection of 127 lecturers as the target respondents of the survey. This study investigated the SQ of private university lecturers who are deemed to be more stressful at work since their responsibility not only involves teaching the students but also ensuring that there are students registered in their courses and that they are employed upon graduation. According to Md. Jani, Md. Shahid, Thomas, and Francis (2015), private university lecturers are required to be involved in these various roles and tasks not only physically but also spiritually and emotionally. In achieving the objectives and hypotheses, this study utilised the IBM-SPSS version 23 for Windows for the statistics and multiple regression analysis.

\section{RESULTS AND DISCUSSIONS}

This study usedthe simple random sampling technique and conducted a cross-sectional data collection within five days. A total of 127 lecturers willingly participated in the survey. The demographic profile tapped female respondents occupying $70 \%$ of the survey, of which the majority $(73 \%)$ were Malays. In general, the respondents have a master degree $(75 \%)$ and work as lecturers (66\%). They are between 26 and 35 years old and have been working between two and five years and earn below RM5, 000 $(43 \%)$ a month. All the lecturers are Malaysians who are teaching various academic courses.

The overall mean for SQ sub-dimensions and Service Quality are shown in Table 1. The mean scores ranged from 4.1 to 4.9 representing the respondents' agreement that SQ has an influence on Service Quality at the universities. The three highest mean scores are Transcendence $($ mean $=$ 4.9), followed by Meaning (mean =4.7), and Consciousness ( mean =4.4). 
Table 1: Summary Item Statistics

\begin{tabular}{lcccccc} 
& Mean & Minimum & Maximum & Range & $\begin{array}{c}\text { Maximum/ } \\
\text { Minimum }\end{array}$ & Variance \\
\hline Truth & 4.074 & 3.598 & 4.598 & 1.000 & 1.278 & .162 \\
\hline Grace & 4.384 & 3.480 & 5.047 & 1.567 & 1.450 & .601 \\
\hline Transcendence & 4.858 & 4.717 & 5.087 & .370 & 1.078 & .030 \\
\hline Meaning & 4.657 & 4.181 & 4.898 & .717 & 1.171 & .104 \\
\hline Consciousness & 4.428 & 3.402 & 4.795 & 1.394 & 1.410 & .336 \\
\hline
\end{tabular}

Validity and reliability for SQ and service quality were checked with Cronbach's alpha coefficient. The rule of thumb posited by many scholars is that an alpha of 0.7 is recommended for a measurement scale. However, as shown in Table 2, after considering all possible deleted items, the SQ variables' internal consistency was slightly low, although exceeding the moderate reliability value of 0.50 , as suggested by Nunnaly (1978).

Table 2: Reliability Statistics

\begin{tabular}{lcl} 
& Cronbach's Alpha & N \\
\hline Truth & .515 & 5 \\
\hline Grace & .582 & 5 \\
\hline Transcendence & .726 & 4 \\
\hline Meaning & .722 & 4 \\
\hline Consciousness & .667 & 5 \\
\hline
\end{tabular}

As demonstrated in Table 3, SQ is a significant predictor. The regression results produced were significant when the SQ dimensions were entered into the regression equation, explaining 37\% variability in Service Quality. Therefore, there was a support for the model $(F(5,121)=13.986 ; p<0.05$; $\left.\mathrm{R}^{2}=0.366 ; \mathrm{R}_{\text {adj }}^{2}=0.340\right)$. In other words, the effect of the combination of five sub-dimensions is significant. The R2 values tell us how well an SQ model predicts the data used to generate the model fit for this study. Generally, in social sciences study, the R2 of around 0.3 to 0.40 is acceptable goodness of fit. The significant result therefore supportsthe hypothesis of this study and further supports the linked causal model proposed by Tischler, Bibierman, and McKeage (2002). The results are parallel to the study done by Martin and Hafer (2009), Rani, Ghani, and Ahmad (2013), to name a few, where 
motivated employees with a high SQ could make a person self-satisfied to the point of performing well at work.

Table 3: Model Summaryb

\begin{tabular}{|c|c|c|c|c|c|c|c|}
\hline \multirow[b]{2}{*}{ Model } & \multirow[b]{2}{*}{$\mathbf{R}$} & \multirow[b]{2}{*}{ R Square } & \multirow{2}{*}{$\begin{array}{l}\text { Adjusted } \\
\text { R Square }\end{array}$} & \multirow{2}{*}{\multicolumn{2}{|c|}{$\begin{array}{l}\text { Std. Error of } \\
\text { the Estimate }\end{array}$}} & \multicolumn{2}{|c|}{ Change Statistics } \\
\hline & & & & & & $\begin{array}{l}\text { R Square } \\
\text { Change }\end{array}$ & $\begin{array}{c}\mathbf{F} \\
\text { Change }\end{array}$ \\
\hline 1 & $.605^{\mathrm{a}}$ & .366 & .340 & & .53674 & .366 & 13.986 \\
\hline \multicolumn{8}{|c|}{ ANOVA $^{a}$} \\
\hline \multicolumn{2}{|r|}{ Model } & \multicolumn{2}{|c|}{$\begin{array}{l}\text { Sum of } \\
\text { Squares }\end{array}$} & df & $\begin{array}{l}\text { Mean } \\
\text { Square }\end{array}$ & $\mathbf{F}$ & Sig. \\
\hline \multirow[t]{3}{*}{1} & Regression & \multicolumn{2}{|c|}{20.146} & 5 & 4.029 & 13.986 & $.000^{\mathrm{b}}$ \\
\hline & Residual & \multicolumn{2}{|c|}{34.859} & 121 & .288 & & \\
\hline & Total & \multicolumn{2}{|c|}{55.004} & 126 & & & \\
\hline
\end{tabular}

a. Dependent Variable: service quality

b. Predictors: (Constant), Meaning, Transcendence, Truth, Grace, Consciousness

Table 4 indicates that Transcendence and Meaning contributed to Service Quality at a significant level; $37.4 \%$ and $30.9 \%$ respectively. This is consistent with other studies by Rezai et al. (2011), Javaheri et al. (2013), Nadi and Golpalvar (2011), Sachro and Pudjiastuti (2013), Saad et al. (2015). In this model, the other SQ dimensions; Truth, Grace, and Consciousness were found to be insignificant when tested against Service Quality. After studying the overall mean values scored (refer Table 1), these three variables were found to be slightly lower than Transcendence and Meaning. The rationale for this outcome can be explained in the following manner. After studying each Cronbach alpha in Table 2, it is evident that the value lower than .7 has impacted the significant results of this study. Zikmund (2013) suggested that the internal consistency of measured items is only acceptable when the threshold is between 0.7 and 0.8 . This is supported by Button et al. (2013) where the low statistical power has an effect on the low reproducibility of the results. 
Table 4: Coefficients

\begin{tabular}{llccccc}
\hline \multirow{2}{*}{$\begin{array}{c}\text { Model } \\
\text { B }\end{array}$} & \multicolumn{2}{c}{$\begin{array}{c}\text { Unstandardized } \\
\text { Coefficients }\end{array}$} & $\begin{array}{c}\text { Standardized } \\
\text { Coefficients }\end{array}$ & \multirow{2}{*}{ t } & Sig. \\
\cline { 2 - 5 } & & Std. Error & Beta & & & \\
\hline 1 & (Constant) & 1.459 & .496 & & 2.939 & .004 \\
& Truth & -.053 & .085 & -.052 & -.624 & .534 \\
& Grace & -.009 & .089 & -.009 & -.098 & .922 \\
& Transcendence & .383 & .084 & .374 & 4.535 & .000 \\
& Consciousness & .123 & .098 & .115 & 1.260 & .210 \\
& Meaning & .268 & .082 & .309 & 3.264 & .001 \\
\hline
\end{tabular}

a. Dependent Variable: service quality

\section{CONCLUSIONS AND RECOMMENDATIONS}

The findings demonstrate that SQ impacts the service quality of lecturers, which then affects students' performance. This study provides knowledge on SQ as well as its preliminary assessment that will prove that lecturers with a high SQ are better educators and are therefore able to contribute meaningfully to service quality. This is particularly so with SQ in the context of transcendence (perfection/wholeness) and meaning (sense) among young lecturers of private universities, thus opening up the issue for further dialogue. This finding is very interesting as it shows that lecturers working in a privately owned university are bound to different management structures. These groups seem happy and are able to work without thinking of other interests, although these private institutions usually require faster decisions and less micromanagement. Perhaps a better incentive-based pay package could make people serve holistically and feel that their work is in service to a larger whole.

The results gained from this study could be used as a guide for all universities, private and public alike when developing new policies that affect lecturers - inculcate SQ among lecturers for inner strength to face day-to-day challenges and in the production of higher quality teaching. In the face of global competition, private universities need to offer synergy and value-added services to the students who are the most important stakeholder in any academic institution. This study implicates the integration of SQ as a significant ingredient of effectiveness, particularly in reducing ethical issues and in heightening morale towards better quality services in teaching and 
educating students. Future studies may want to look into whom and what is responsible for developing a lecturer's inner strength named SQ.

\section{REFERENCES}

Abels, S. (2000). Spirituality in social work practice: Narratives for professional helping. Denver, CO.: Love Publishing.

Agbor, J. M. (2011). The relationship between customer satisfaction and service quality: A study of three service sectors in Umeå.

Ahmad Shah, N., Saad, M., Mohamed Mohan, N. M., \& Poniran, H. (2018, 3-4 March). The impact of emotional intelligence on the job effectiveness of private university lecturers. Paper presented at the International Conference on Business, Humanities and Education (ICBHE 2018), Bayview Beach Resort, Batu Ferringhi, Penang, Malaysia.

Akintayo, D. I., \& Babalola, S. S. (2012). The impact of EQ on workers' behavior in industrial organization. Journal Human \& Social Science, 4(2), 83-90.

Al-Turki, U., \& Duffuaa, S. (2003). Performance measures for academic departments. International Journal of Educational Management, 17(6/7), 330-338.

Amram, Y., \& Dryer, C. (2007). The Integrated Spiritual Intelligence Scale (ISIS): Development and Preliminary Validation. Paper presented at the 116th Annual Conference of the American Psychological Association, Boston, MA. Retrieved from http://www.yosiamram.net/papers

Avdjieva, M., \& Wilson, M. (2002). Exploring the development of quality in higher education. Managing Service Quality, 12(6), 372-383.

Barnes, S. J., \& Vidgen, R. (2003). Measuring web site quality improvements: A case study of the forum on strategic management knowledge exchange. Industrial Management \& Data Systems, 103, 297-309. 
Brady, M. K., \& Cronin, J. J. (2001). Some new thoughts on conceptualising perceived service quality: A hierarchical approach. Journal of Marketing, 65(3), 34-49.

Button, K., Ioannidis, J., Mokrysz, C., Nosek, B., Flint, J., Robinson, E., \& Munafò, M. (2013). Power failure: Why small sample size undermines the reliability of neuroscience. Nature Reviews Neuroscience, 14, 365376.

Chin, S. T. S., Anantharaman, R. R. N., \& Tong, D. Y. K. (2011). Analysis of the level of emotional intelligence among executives in small and medium sized enterprises. Journal of Human Resources Management Research, 1-13.

Crisp, B. R. (2018). Religion, spirituality and social work: An international perspective. International Journal of Human Rights in Healthcare, 11(2), 91-99.

Croasmun, J. T., \& Ostrom, L. (2011). Using Likert-type scales in the social sciences. Journal of Adult Education, 40(1), 19-22.

Dabholkar, P. A., Thorpe, D. I., \& Rentz, J. O. (1996). A measure of service quality for retail stores: Scale development and validation. Journal of the Academy of Marketing Science 24(1), 2-16.

Elizabeth, S. K., \& Steven, B. W. (2007). EQ competencies in the team and team leader: A multi-level examination of the impact of EQ on team performance. Journal of Management Development, 27, 55-75.

Flynn, F. (2005). Identity orientations and forms of social exchange in organizations. Academy of Management Review, 30(4), 737-750.

Fry, L. W. (2003). Toward a theory of spiritual leadership. The Leadership Quarterly, 14(6), 693-727.

George, R. M., \& Visvam, S. (2013). Spiritual intelligence, its correlation with teacher effectiveness and academic achievement - A Study. International Journal of Education and Psychological Research, 2(2), 106-110. 
Gill, A., Mand, H. S., Biger, N., \& Mathur, N. (2018). Influence of religious beliefs and spirituality on decision to insure. International Journal of Emerging Markets, 13(5), 780-800.

Haji, J., Bemby, A. B., \& Sentosa, I. (2013). The intelligence, emotional, spiritual quotients and quality of managers. Global Journal of Management and Business Research Administration and Management, 13(3), 1-12.

Harries, M., (1998). Spirituality and trauma therapy. Australian Association of Social Work (AASW) Newsletter, 82, 187-193.

Hay, D., \& Nye, R. (1998). The spirit of the child. London: Harper Collins.

Hays, J. M., \& Hill, A. V. (2006). Service guarantee strength: The key to service quality. Journal of Operations Management, 24(6), 753-764.

Ismail, A., Suh, Y. S., Ajis, M. N. E., \& Dollah, N. F. (2009). Relationship between occupational stress, emotional intelligence and job performance: An Empirical study in Malaysia. Theoretical and Applied Economics, 10(6), 3-16.

Jafari, A., \& Rastegar, H. (2007). The emergence of spirituality in organizations, concepts, definitions, assumptions and concept method. Journal of Management Science, 5, 99-121.

Javaheri, H., Bahonar, S., \& Safarnia, H. (2013). Survey relationship between spiritual intelligence and service quality. Interdisciplinary Journal of Contemporary Research in Business, 4(9), 547-554.

Jha, A., \& Singh, I. (2012). Teacher effectiveness in relation to emotional intelligence among medical and engineering faculty members. Europe's Journal of Psychology, 8(4), 667-685.

Joshanloo, M. (2010). Investigation of the contribution of spirituality and religiousness to hedonic and experience. American Behavioral Scientist, $45,1886-1899$. 
Kuei, C. H., \& Madhu, C. N. (1995) Managers' perceptions of factors associated with quality dimensions for the different types of firms. Quality Management Journal, 2, 67-80.

Lassar, W. M., Manolis, C., \& Winsor, R. D. (2000). Service quality perspectives and satisfaction in private banking. International Journal of Bank Marketing, 14(3), 244-271.

Madhu, C. N., Kuei, C. H., \& Jacob, R. A. (1996). An empirical assessment of quality dimensions on organizational performance. International Journal of Production Research, 34, 1943-1962.

Mahmood, A., Arshad, M. A., Ahmed, A., Akhtar, S., \& Khan, S. (2018). Spiritual intelligence research within human resource development: A thematic review. Management Research Review, 41(8), 987-1006.

Mansor, Z. D., \& Han, C. K. (2013). Changes in demand: The roles of academic leaders in Malaysia. Researcher World, 4(3), 54-62.

Martin, N. T., \& Hafer, J. C. (2009). Models of emotional intelligence, spiritual intelligence, and performance: A test of Tischler, Biberman, and McKeage.

Mayer, J. D., \& Salovey, P. (1993). EQ and construction of feelings. Applied and Preventive Psychology, 4, 197-208.

McGuire, M. B. (1993). Health and spirituality as contemporary concern. Annals of the American Academy of Political \& Social Science, 527, 144-155.

Md. Jani, S. H, Md. Shahid, S. A., Thomas, M., \& Francis, P. (2015). The predictors of lecturers' teaching effectiveness for public and private universities in Malaysia, International Journal of Social Science and Humanity, 5(4), 384-388.

Moore, T. W., \& Casper, W. J. (2006). An examination of proxy measures of workplace spirituality: A profile model of multidimensional constructs. Journal of Leadership and Organizational Studies, 12(4), 109-111. 
Nadi, M. A., \& Golparvar, M. (2011). Simple and integrative relationship between spirituality components with loyalty at work. Ethics in Science and Technology, 6(2), 13-21.

Narimawati, S. E. U. (2007). The influence of work satisfaction, organizational commitment and turnover intention towards the performance of lecturers at West Java's private higher education institution. Journal of Applied Sciences Research, 3(7), 547-557.

Nolan-Aranez, S. I., \& Ludvik, M. B. (2018). Positing a framework for cultivating spirituality through public university leadership development. Journal of Research in Innovative Teaching \& Learning, 11(1), 94-109.

Nunnaly, J. C. (1978). Psychometric theory (2nd. ed.). New York: McGrawHill.

O’Neill, M., \& Palmer, A. (2004). Importance-performance analysis: A useful tool for directing continuous quality improvement in higher education. Quality Assurance of Education, 12, 39-52.

Parasuraman, A., Zeithaml, V., \& Berry, L. L. (1985). A conceptual model of service quality and its implications for future research. Journal of Marketing, 49, 41-50.

Parasuraman, A., Zeithaml, V., \& Berry, L. L. (1988). SERVQUAL: A multiple-item scale for measuring consumer perceptions of service quality. Journal of Retailing, 64, 12-40.

Parasuraman, A., Zeithaml, V., \& Berry, L. L. (1991). Refinement and reassessment of the SERVQUAL scale. Journal of Retailing, 67, $420-450$.

Parasuraman, A., Zeithaml, V., \& Berry, L. L. (1994). Reassessment of expectations as a comparison standard in measuring service quality: Implications for future research. Journal of Marketing, 58, 111-124.

Pargament, K. I. (1999). The psychology of religion and spirituality? Yes and no. International Journal for the Psychology of Religion, 9(1), 3-16. 
Perez, J. A. (2012), Gender difference physiological well-being among Filipino college students' samples. International Journal of Humanities and Social Science, 2(13), 84-93

Petrosko, J. M., \& Alagaraja, M. (2017). Research suggestions for management, spirituality, religion. Management Research Review, 40(8), 933-952.

Ramachandaran, S. D., Krauss, S. E. Hamzah, A., \& Idris, K. (2017). Effectiveness of the use of spiritual intelligence in women academic leadership practice. International Journal of Educational Management, $31(2), 160-178$.

Rani, A. A., Ghani, A. A., \& Ahmad, S. (2013). The impact of spiritual intelligence in reducing job stress: Case studies in Malaysia University of East Coast of Malaysia. Macrotheme Review, 2(4), 183-192.

Rezai, H., Kazemi, A., \& Isfahani, M. N. (2011). An analysis of spiritual intelligence effect on marketing performance and innovation in sales and marketing unit (Case study: Isfahan Mobarakeh Steel Company). Interdisciplinary Journal of Contemporary Research in Business, 3(6), 683-692.

Rupcic, N. (2017). Spiritual development - A missing and powerful leverage when building learning organizations. The Learning Organization, 24(6), 418-426.

Rust, R. T., \& R. L. Oliver. (1994). Service quality: Insights and managerial implications from the frontier. In R. T. Rust, \& R. L. Oliver (Eds.), Service quality: New directions in theory and practice (pp. 1-19). Thousand Oaks:California CA: Sage.

Saad, M. Husain, R., Mahayuddin, N., Ahmad, A., \& Kumarasamy, M. M. (2018). Is spiritual intelligence no longer relevant on business performance? International Journal of Engineering and Technology (UAE), 7(3), 27-31. 
Saad, M., Husain, R., Nawi, W. N. F. W., \& Mahyuddin, N. (2017). Coming back for more quality learning experience. Asian Journal of Quality of Life (AjQoL), 3(12), 23-32.

Saad, M., Husain, R., Rani, A. A., \& Ghani, A. A. (2019). Empowering employees with spiritual intelligence for higher quality food-hygiene practices and food service performance of on-premise caterers. IOP Conference Series: Materials Science and Engineering, 469(1), 012066.

Saad, M., See, T. P., Adil, M. A. M., \& Kassim, N. (2015). Spiritual intelligence on leadership effectiveness and food-hygiene practices in public institutions. Procedia - Social and Behavioral Sciences, 201, 146-155.

Saad, M., See, T. P., Adil, M. A. M., \& Ab Manan, S. K. (2014, 2-3 September 2013). Perceived leadership effectiveness on food handlers' spiritual intelligence in food service business. Paper presented at the Hospitality and Tourism Postgraduate Conference 2013, Shah Alam, Malaysia.

Saad, M., See, T. P., Adil, M. A. M., \& Md Kassim, N. (2015). A holistic perspective of spiritual intelligence on leadership effectiveness and food-hygiene practices in government fo odservice institutions. Procedia - Social and Behavioral Sciences.

Sachro, \& Pudjiastuti, S. R. (2013). The effect service quality to customer satisfaction and loyalty of Argo Bromo Anggrek Train Jakarta-Surabaya in Indonesia. IOSR Journal of Business and Management, 12(1), 33-38.

Saleh, F., \& Ryan, C. (1991). Analyzing service quality attributes and choice behavior. Journal of Service Marketing, 7, 59-68.

Salehi, M., Mirzaee, M. A., \& Yazdani, M. (2017). Spiritual and emotional intelligences, financial performance, tax avoidance and corporate disclosure quality in Iran. International Journal of Law and Management, 59(2), 237-256. 
Saravanon, R., \& Roak, S. P. (2007). Measure the service quality from customer perception of service quality. Total Quality Management, $18,435-449$.

Shaik, S. A. (2018). Making sense of our existence: The scientific and religious worldview. International Journal of Ethics and Systems, 34(4), 593-607.

Smith, A. M. (2000). Using consumer benchmarking criteria to improve service sector competitiveness. Benchmarking: An International Journal, 7(5), 373-388.

Srivastava, A., \& Misra, S. (2012). Is spiritual quotient a better tool of success: Spirituality in the new world order. EXCEL International Journal of Multidisciplinary Management Studies, 2(1), 256-266..

Sureshchandar, G. S., Rajendran, C., \& Kamalanabhan, T. J. (2001). Customer perceptions of service quality - A critique. Total Quality Management, 12, 111-124.

Tischler, L., Biberman, J., \& Mckeage, R. (2002). Linking emotional intelligence, spirituality and workplace performance. Journal of Managerial Psychology, 42(2), 16-33.

Van Niekerk, B. (2018). Religion and spirituality: What are the fundamental differences? HTS Teologiese Studies/Theological Studies, 74(3), 1-11.

Vaughan, F. (1991). Spiritual issues in psychotherapy. The Journal of Transpersonal Psychology, 23, 105-119.

Watkins, J. (2003). Spiritual Guidance. People Management, 20 February, p.17.

White, N. R. (2007). The customer is always right? Student discourse about higher education in Australia. Higher Education, 54(4), 593-604.

Wirawan, H., Jufri, M., \& Patak, A. A. (2018). Spiritual group training for adolescences: Investigating the effect of group training on spiritual 
well-being. International Journal for Lesson and Learning Studies, $7(1), 62-74$

Yarmohammadian, M. H., Foroughi Abari, A. A., Anasri, M., \& Kiani, H. (2009). Using strategic planning model to improve Iran higher education NG-NP. Paper presented at the International Conference on Technology and Business Management, Al Ghuraair University, United Arab Emirates.

Zikmund, W. G., Babin, B. J., Carr, J. C., \& Griffin, M. (2013). Business research methods $\left(9^{\text {th }}\right.$ ed.). Mason, OH: South-Western/Cengage Learning.

Zohar, D., \& Marshall, I. (2000). SQ: Spiritual intelligence: The ultimate intelligence. London: Bloomsbury. 